\title{
Association between Receptive Language Skill and Social Communication Skill among Preschool Children: Path Analysis Evidence from Surakarta, Central Java
}

\author{
Nadya Susanti'), Eti Poncorini Pamungkasari²), Rita Benya Adriani3) \\ ${ }^{1)}$ Masters Program in Public Health, Universitas Sebelas Maret \\ 2) Faculty of Medicine, Universitas Sebelas Maret \\ ${ }^{3)}$ Health Polytechnics Ministry of Health, Surakarta
}

\section{ABSTRACT}

Background: Children with social communication problems run the risk of academic failure, difficulty forming friendships, social exclusion, and withdrawal. The ability of social communication is influenced by several factors including receptive language skills, parenting patterns, child birth order, and gender. The purpose of this study was to analyze the relationship between receptive language skills and social communication skills using path analysis.

Subjects and Method: This was a cross sectional study conducted in Surakarta, Central Java, in January 2020. A sample of 200 children aged 4-6 years was selected using a random sampling technique. The dependent variable was the ability of social communication. The independent variable was receptive language ability, parenting, birth order, and gender. Data collection was performed using a questionnaire and analyzed by path analysis using Stata 13.

Cite this as:

Susanti N, Pamungkasari EP, Adriani RB (2020). Association between Receptive Language Skill and Social Communication Skill among Preschool Children: Path Analysis Evidence from Surakarta, Central Java. J Matern Child Health. 5(3): 226-234. https://doi.org/10.26911/thejmch.2020.05.03.01

cc (i) (2) Journal of Maternal and Child Health is licensed under a Creative Commons

EY NA Attribution-Non Commercial-Share Alike 4.o International License.

\section{BACKGROUND}

Social communication is the use of language in a social context that includes social interaction, social cognition, pragmatics, and language processing (Shipley and McAfee, 2015). The basis of social communication is done by increasing the relationship between children and peers. Children cannot communicate properly can cause children to be ostracized or shunned by the environment. The process of good social communication is able
Results: Good social communication skill was directly increased by good receptive language skill $(b=3.21 ; 95 \% \mathrm{CI}=0.50$ to $2.07 ; \mathrm{p}=0.001)$, first birth order $(b=3.11 ; 95 \% \mathrm{CI}=0.45$ to 1.99; $\mathrm{p}=0.002)$, democratic parenting style $(\mathrm{b}=4.94$; $95 \% \mathrm{CI}=1.40$ to $3.24 ; \mathrm{p}<0.001$ ), and female gender $(b=5.49 ; 95 \% \mathrm{CI}=1.41$ to $2.98 ; \mathrm{p}<0.001)$. Conclusion: Good social communication skill is directly increased by good receptive language skill, first birth order, democratic parenting style, and female gender.

Keywords: Social communication skills, receptive language skills

\section{Correspondence:}

Nadya Susanti. Masters Program in Public Health. Universitas Sebelas Maret, Jl. Ir. Sutami 36A, Surakarta, Jawa Tengah, Indonesia, 57126. Email: nadyasusanti3@gmail.com. Mobile: 081568222014

to carry out the purpose of interaction and becomes a problem if children can interact by behaving unethically or socially inappropriate (Blackwell, 2018).

The estimated population of Social Communication Disorders in pre-school age children is $7.5 \%$ with a ratio of boys: girls (Swine-ford et al., 2014) whereas according to Cocquyt et al. (2015) Social Communication Disorders occur in 5-10\% of children under 6 years of age. Miranda et al. (2019) re- 
ported as much as $7 \%$ with a ratio between men: women, with ratios ranging from 2.8: 1 to 4.8: 1 .

The number of preschool children in Indonesia in 2018 was 9,613,386, the highest prevalence was in West Java province by 1,744,261 and North Kalimantan Province had the lowest prevalence of 29,707 while Central Java Province was in third place with 1,095,947 (Ministry of Health, 2019). The number of pre-school age children in Surakarta City is 24,791 (DISPENDUKCAPIL, 2018). Referring to the opinion of Sari et al. (2015) and Miranda et al. (2019) the prevalence of Social Communication Disorders and language problems ranges from 5-10\% then it can be estimated in Indonesia as much as 480,669-961,338, in Central Java as many as 54,797-109,594 children and in Surakarta as many as 1,239-2,479 children.

Esparza et al. (2016) in his study stated that the ability of social communication increases the quantity and quality of children's social behavior so that it is more mature in social behavior in social situations. Children with Social Communication Disorders experience a deficit in pragmatic and language development where it affects social functioning (Adams et al., 2015). Yildiz et al. (2019) states that receptive language influences the development of children's domains, namely communication skills, gross motor skills, fine motor skills, problem solving and social personal relationships. Good receptive language development also influences cognitive development, academic success, and children's ability to communicate socially in the community (Paul et al., 2017).

The second child or so must compete with their sister to get the attention of the mother. The situation was partly compensated by the extra attention given by the older siblings. The first child can adjust the way of communication when communicating with his younger sibling, but the way of communi- cation of preschool-aged children for their younger siblings also has many different aspects of communication carried out by the mother. How to communicate preschoolers contains more direction and fewer questions than mothers do (Rudolph, 2017).

Parenting patterns affect the ability of social communication, parents who always use verbal communication in teaching children will have an impact on children's social communication skills better than parents who use non-verbal communication more often (Litchman, 2016). Boys have a tendency to be more difficult to communicate than girls (Adani and Capenac, 2019) where sentences in boys' communication are shorter and the grammar produced is less correct than girls and the vocabulary of boys is more few (Stolarova et al., 2016).

\section{SUBJECTS AND METHOD \\ 1. Study Design}

This was a cross sectional study conducted in 8 Surakarta Kindergartens, namely Bibis Luhur Christian Kindergarten, Surakarta Calvary Kindergarten, Bakti XI Islamic Kindergarten, RA Al Kautsar Kindergarten, Siloam Kindergarten, Pembina Negeri Kindergarten, Sri Juwita Hanum Kindergarten, and Aisyiyah Al Amin Kindergarten.

\section{Population and Sample}

The study population was children. A sample of 200 children aged 4-6 years was selected by simple random sampling.

\section{Study Variables}

The dependent variable was the ability of social communication. The independent variables were receptive language skills, birth order, parenting, and gender.

\section{Operational Definition of Variables} Social communication was the use of language in a social context that includes social interaction, social cognition, pragmatics and language processing. The data were collected by questionnaire. The measurement scale 
was continous, but for data analysis, it was transformed into dichotomous, coded $\mathrm{O}=$ poor and $1=$ good.

Receptive language ability was the ability of a person to recognize and interact with someone, understand the circumstances surrounding, understand the expression of the other person, and understand the tone of the other person's voice. The data were collected by questionnaire. The measurement scale was continous, but for data analysis, it was transformed into dichotomous, coded $\mathrm{O}=$ poor and $1=$ good.

Birth order was the position of the child based on the order of birth in the family which influences further development. The data were collected by questionnaire. The measurement scale was continous, but for data analysis, it was transformed into dichotomous, coded $o$ for $>1$ and 1 for first child.

Parenting was a pattern of behavior that parents apply to children and is relatively consistent over time. The data were collected by questionnaire. The measurement scale was continous, but for data analysis, it was trans- formed into dichotomous, coded $\mathrm{o}=$ poor and $1=$ good.

Gender was the difference between men and women biologically from birth. The data were collected by questionnaire. The measurement scale was continous, but for data analysis, it was transformed into dichotomous, coded $\mathrm{O}=$ male and $1=$ female.

\section{Data Analysis}

Univariate analysis aims to generally describe each of the variables studied. Bivariate analysis was performed by chi-square. Multivariate analysis was conducted by path analysis.

\section{Research Ethics}

The protocol in this study was approved by the Health Research Ethics Committee, Dr. Moewardi Hospital, Surakarta with number: 117/I/HREC/2O2O.

\section{RESULTS}

\section{Sample Characteristics}

Sample characteristics of continous data were described in Table 1. Sample characteristics of categorical data were described in Table 2.

Table 1. Sample characteristics (continous data)

\begin{tabular}{lccccc}
\hline \multicolumn{1}{c}{ Variables } & N & Mean & SD & Min. & Max. \\
\hline Receptive language skills & 200 & 74.3 & 15.26 & 40 & 99 \\
Parenting style & 200 & 23.92 & 4.73 & 6 & 30 \\
Social Communication Skills & 200 & 8.77 & 2.29 & 3 & 14 \\
\hline
\end{tabular}

Table 2. Sample Characteristics (categorical data)

\begin{tabular}{lcc}
\hline Characteristics & Frequency (n) & Percentage (\%) \\
\hline Receptive Language Skills & 79 & 60.50 \\
Poor & 121 & 39.50 \\
Good & & \\
Birth Order & 77 & 38.50 \\
Second or more child & 123 & 61.50 \\
First child & & \\
Parenting & 57 & 28.50 \\
Poor & 143 & 71.50 \\
Good & & \\
Gender & 84 & 42.00 \\
Male & 116 & 58.00 \\
Female & & \\
Social Communication Skill & 95 & 47.50 \\
Poor & 105 & 52.50 \\
Good & & \\
\hline
\end{tabular}


Table 2 showed that children with good receptive language skills were 121 (60.50\%). Birth order variables indicate that 139 are the first children (69.50\%). Children who get democratic parenting style were 143 (71.50\%). As many as of 116 children (58\%) were female and 84 children (42\%) were

\section{male \\ skill.}

Table 3 Chi-square test the relationship of receptive language skills, birth order, parenting, gender, and social communication skills

\begin{tabular}{|c|c|c|c|c|c|c|c|c|}
\hline \multirow{3}{*}{ Independent Variables } & \multicolumn{4}{|c|}{ Social Communication Skill } & \multirow{2}{*}{\multicolumn{2}{|c|}{ Total }} & \multirow{3}{*}{ OR } & \multirow{3}{*}{$\mathbf{P}$} \\
\hline & \multicolumn{2}{|c|}{ Good } & \multicolumn{2}{|c|}{ Poor } & & & & \\
\hline & $\mathbf{n}$ & $\%$ & $\mathbf{n}$ & $\%$ & $\mathbf{N}$ & $\%$ & & \\
\hline \multicolumn{9}{|l|}{ Receptive Language Skills } \\
\hline Poor & 29 & 36.71 & 50 & 63.29 & 79 & 100 & 2.91 & $<0.001$ \\
\hline Good & 76 & 62.81 & 45 & 37.19 & 121 & 100 & & \\
\hline \multicolumn{9}{|l|}{ Birth Order } \\
\hline Second or more child & 27 & 35.06 & 50 & 64.94 & 77 & 100 & 3.20 & $<0.001$ \\
\hline First child & 78 & 63.41 & 45 & 36.59 & 123 & 100 & & \\
\hline \multicolumn{9}{|l|}{ Parenting } \\
\hline Poor & 10 & $17 \cdot 54$ & 47 & 82.46 & 57 & 100 & 9.30 & $<0.001$ \\
\hline Good & 95 & 66.43 & 48 & 33.57 & 143 & 100 & & \\
\hline \multicolumn{9}{|l|}{ Gender } \\
\hline Male & 21 & 25.00 & 63 & 75.00 & 84 & 100 & 7.87 & $<0.001$ \\
\hline Female & 84 & 72.41 & 32 & 27.59 & 116 & 100 & & \\
\hline
\end{tabular}

\section{Path analysis}

Figure 1 showed a path analysis model of the factors related to social communication skills. It showed that social communication skill

\section{The result of bivariate analysis}

Table 3 shows the results of the bivariate analysis. Good receptive language skills $(\mathrm{OR}=$ 2.91; $\mathrm{p}<0.001)$, democratic parenting $(\mathrm{OR}=$ 9.30; $\mathrm{p}<0.001)$, female gender $(\mathrm{OR}=7.87 ; \mathrm{p}$ $<0.001)$, and birth order $(\mathrm{OR}=3.20$; $\mathrm{p}$ $<0.001)$ increased social communication

was directly associated with receptive language skill, parenting style, female gender, and birth order.

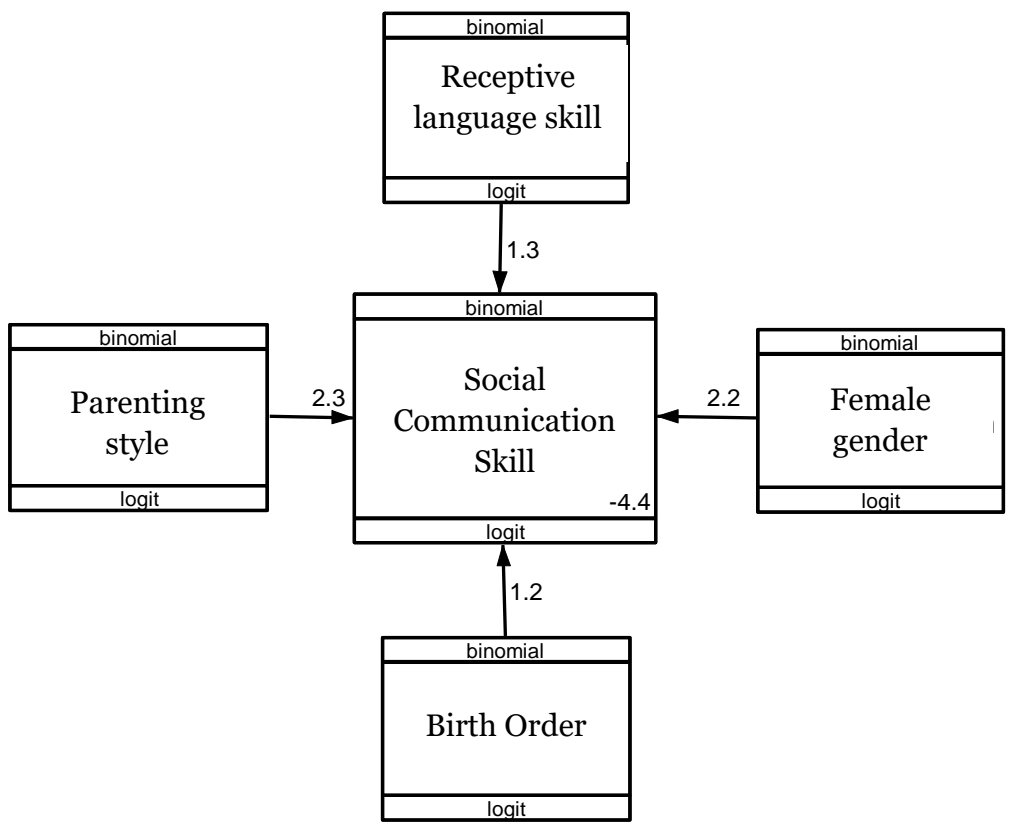

Figure 1 path analysis diagram 
Susanti et al./Association between Receptive Language Skill and Social Communication Skill

Table 4 Path analysis of the relationship of receptive language skills, birth order, parenting style, gender, and social communication skills.

\begin{tabular}{|c|c|c|c|c|c|c|}
\hline \multirow{2}{*}{\multicolumn{2}{|c|}{ Dependent Variable }} & \multirow{2}{*}{$\begin{array}{c}\text { Independent } \\
\text { Variable }\end{array}$} & \multirow{2}{*}{$\begin{array}{l}\text { Path Coef- } \\
\text { ficient (b) }\end{array}$} & \multicolumn{2}{|c|}{$95 \%$ CI } & \multirow[b]{2}{*}{$\mathbf{p}$} \\
\hline & & & & $\begin{array}{l}\text { Lower } \\
\text { Limit }\end{array}$ & $\begin{array}{l}\text { Upper } \\
\text { Limit }\end{array}$ & \\
\hline \multirow{4}{*}{$\begin{array}{l}\text { Direct Effect } \\
\text { Social Communi- } \\
\text { cation Skill }\end{array}$} & & & & & & \\
\hline & $\leftarrow$ & $\begin{array}{l}\text { Receptive } \\
\text { language skill } \\
\text { (good) }\end{array}$ & 3.21 & 0.50 & 2.07 & 0.001 \\
\hline & $\leftarrow$ & $\begin{array}{l}\text { Birth order (first } \\
\text { child) }\end{array}$ & 3.11 & 0.45 & 1.99 & 0.002 \\
\hline & $\leftarrow$ & $\begin{array}{l}\text { Parenting style } \\
\text { (democratic) }\end{array}$ & 4.94 & 1.40 & 3.24 & $<0.001$ \\
\hline \multicolumn{3}{|c|}{$\begin{array}{l}n \text { observation }=200 \\
\text { Log Likelihood }=-88.02\end{array}$} & 5.49 & 1.41 & 2.98 & $<0.001$ \\
\hline
\end{tabular}

Table 4 shows good social communication of children aged 4-6 years increased with good receptive language skills $(\mathrm{b}=3.2 ; 95 \% \mathrm{CI}=$ 0.50 to 2.07; $\mathrm{p}=0.001$ ), birth order of first child $(b=3.11 ; 95 \% \mathrm{CI}=0.45$ to $1.99 ; \mathrm{p}=$ o.002), democratic parenting ( $b=4.94 ; 95 \%$ $\mathrm{CI}=1.40$ to $3.24 ; \mathrm{p}<0.001)$ and female $(\mathrm{b}=$ $5.49 ; 95 \% \mathrm{CI}=1.41$ to $1.412 .98 ; \mathrm{p}<0.001)$.

\section{DISCUSSION}

1. The relationship between receptive language skills and social communication skills

The results showed a direct relationship between receptive language skills and social communication skills. Chiat and Roy (2019) found that children who have language skills problems early on will experience social communication problems.

Freed et al. (2015) states that children with social communication disorders have poor abilities in developing skills and problems in interpreting a conversation. Brinton and Fujiki (2017) state that children with limited/ poor understanding (receptive) and expressive abilities are at risk of academic failure.

Another impact of poor language skills is that children will also have poor social communication skills so that the impact on difficulties forming friendships, social exclu- sion, and withdrawal. In line with the study of Norbury et al. (2016) states that children with language problems exhibit symptoms of social, emotional and behavioral communication problems which also have an impact on academic ability.

\section{The relationship between birth order and social communication skills}

The results showed a direct relationship between birth order and social communication skills. Volkom et al. (2017) states that children born first have a tendency to more easily communicate with their parents than children born later. The first child will get an abundance of affection and more time than the second child, with an abundance of affection and this time the child feels cared for and accepted by his parents.

This is in line with the study of Bornstein et al. (2019) which states that the fewer family members, the easier it is for children to communicate, because it makes children have more opportunities to communicate with other family members. Parents are more able to set aside time to communicate with children so that children's communication skills are getting better. 


\section{The relationship between parenting and social communication skills}

The results showed a direct relationship between parenting and social communication skills. Litchman (2016) states that parents who always use verbal communication in teaching children will have an impact on children's social communication skills better than parents who use nonverbal communication more often. Sudarman and Mangunsong (2019) stated that the better the parenting applied by parents to children with autism, the better the child's social communication skills.

Parenting in children with autism such as accompanying children during the therapeutic process, teaching children back at home according to therapist's advice has a good impact on aspects of social communication such as, children want to talk and interact with others even if only a word or two (Brown, 2016) . Provision of intervention for children with autism for 3 months (Hansen et al., 2016) namely by involving parents to always invite children to play and communicate can improve children's social communication skills. Parents also need to start building a better environment for the development of children's social communication (Itzchak et al., 2016). Strategies to improve children's social communication skills by providing parenting patterns such as social involvement, imitation, play, and communication (Frost et al., 2019). Good communication patterns provided by parents can improve children's social communication skills when outside the home (Feldman, 2019).

\section{The relationship between gender} and social communication skills

The results showed a direct relationship between gender and social communication skills. Adani and Capenac (2019) and Stolarova et al. (2016) states that the sentences produced by boys in communication are shorter and the grammar produced is less correct than girls and the vocabulary of boys is less. Eriksson (2016) conducted a Communicative Development Inventory III (CDIIII) examination of Swedish children aged 2 years 6 months to 4 years, which included vocabulary, grammar abilities and metalinguistic awareness stating that female communication had higher scores taller than men at all stages.

Umek and Peklaj (2017) state that girls have better social communication skills than men seen in aspects of language skills, vocabulary, sentence complexity, receptive and expressive language, storytelling skills and metalinguistic awareness. Bishop et al. (2016) conducting study with the same sample criteria (non-verbal IQ and age) shows that girls have better social communication skills than boys. Women have a greater capacity in understanding and feeling feelings of cognitive empathy (perspective taking and emotional understanding (Moreno et al., 2016).

\section{AUTHOR CONTRIBUTION}

Nadya Susanti collected study data, formulated study articles and processed the data. Eti Poncorini Pamungkasari examined the background and discussion of the study. Rita Benya Adriani formulated a framework of thinking and analyzing study data.

\section{CONFLICT OF INTEREST}

There is no conflict of interest in this study.

\section{FUNDING AND SPONSORSHIP}

This study is self-funded.

\section{ACKNOWLEDGEMENT}

Authors would like to thank Christian Bibis Luhur Kindergarten, Surakarta Kalvari Kindergarten, Bakti XI Islamic Kindergarten, RA Al Kautsar Kindergarten, Siloam Kindergarten, Pembina Negeri Kindergarten, Sri Juwita Hanum Kindergarten and Aisyiyah Al Amin Kindergarten who have permitted this study. 


\section{REFERENCE}

Adams C, Gaile J, Lockton E, Freed J (2015). Integrating language, pragma-tics, and social intervention in a single-subject case study of a child with a developmental social com-munication disorder. J Speech Lang Hear Res, 46(4): 294-311.doi: 10.1044/2015_LSHSS-140084 .

Adani S, Capenac M (2019). Sex differences in early communication development: behavioral and neurobiological indicators of more vulnerable communication system development in boys. Croat Med J, 60:141-149. doi: 10.3325/cmj.2019.60.141

Bishop SL, Havdahl KA, Huerta M, Lord C (2016). Sub dimensions of social-communication impairment in autism spectrum disorder. J Child Psychol Psychiatry, 57(8): 909-916. doi: 10.1111/jcpp.12510

Blackwell W (2018). The handbook of psycholinguistics. First Edition. University of Washington: John Wiley \& Sons, Inc.

Bornstein MH, Putnick DL, Suwalsky JTD (2019). Mother-infant interactions with firstborns and secondborns: A within-family study of European Americans. Infant BehavDev, 55: 100-111. doi: 10.1016/j.infbeh.2019.03.009.

Brinton B, Fujiki M (2017). The power of stories: Facilitating social communication in children with limited language abilities. School Psychology International, 38(5): 523-540. https://doi.org/10.1177/0143034317713348

Brown JA (2016). Coaching in parent implemented early communication intervention: Understanding and over coming individual-level implementation barriers. American Speech Language Hearing Association, 1(4): 144-153. doi: 10.1044/persp1.SIG1.144
Chiat S, Roy P (2019). The early sociocognitive: clinical tool for early identification of children at risk for social communication diffoculties and ASD. Int J Lang CommunDisord, 54(5): 794-805. doi: 10.1111/1460-6984.12477

Cocquyt M, Mommaerts MY, Dewart H, Zink I (2015). Measuring pragmatic skills: early detection of infants at risk for communication problems. Int J Lang CommunDisord, 50(5): 646-58. doi: 10.1111/1460-6984.12167

DISPENDUKCAPIL (2018). Profil perkembangan kependudukan kota Surakarta tahun 2018 (Profile of the population development of the city of Surakarta in 2018). Surakarta: DISPENDUKCAPIL. https://dispendukcapil.surakarta.go.id /wpcontent/uploads/2019/o9/profil_2 01802_ska.pdf

Eriksson E (2016). The Swedish communicative development inventory III: Parent reports on language in pre-school children. International Journal of Behavioral Development, 41(5): 647-654. https://doi.org/10.1177/-0165025416644078

Esparza NR, Sierra AG, Kuhl PK (2016). The impact of early social interactions on later language development in SpanishEnglish bilingual's infants. Child Dev, 88(4): 1216-1234. doi: 10.1111/cdev.12648.

Feldman HM (2019). How young children learn language and speech. Pediatr Rev, 40(8): 398-411. doi: 10.1542/pir.20170325 .

Freed J, McBean K, Adams C, Lockton E, Nash M, Law J (2015). Performance of children with socialcommunication disorder on the happé strange stories: Physical and mental state responses and relationship tolanguage ability. $\mathrm{J}$ CommunDisord, 55: 1-14. doi: 10.1016/j.jcomdis.2015.03.002. 
Susanti et al./Association between Receptive Language Skill and Social Communication Skill

Frost KM, Koehn GN, Ruseell KM, Ingersoll $B$ (2019). Measuring child social communication across contexts: Similarities and differencesacross play and snack routines. Autism Res, 12(4): 636644. doi: 10.1002/aur.2077.

Hansen AN, Watson SF, McConachie H, Kaale A (2016). Relations between specific and global outcome measures in a social-communication inter-vention for children with autism spectrum disorder. Research in Autism Spectrum Disorders, 29:19-29. http://dx.doi.org/10.1016/j.rasd.2016.05.005

Itzchak EB, Zulkarnaen G, Zachor DA (2016). Having older siblings is associated with less severe social communication symptoms in young children with autism spectrum disorder. J Abnorm Child Psychol, 44(8): 1613-1620. doi: 10.1007/s10802-016-0133-0

KEMENKES (2019). Data dan informasi profil kesehatan infonesia tahun 2018. Kementerian KesehatanRepublik Indonesia. https://www.depkes.go.id/resources/download/pusdatin/profil-kesehatan-indonesia/Data-dan-Informasi_Profil-Kesehatan-Indone-sia-2018.pdf Litchman TG (2016). Verbal versus nonverbal primavy: children's response to parental incongruent communication. Journal of Social and Personal Relationships, 34(5): 636-661. doi: 10.1177/0265407516651158

Miranda A, Berenguer C, Rosello B, Baixaulli I (2019). Relationships between the social communication questionnaire and pragmatic language, socialization skills, and behavioral problems in children with autism spectrum disorders. Applied Neuro-psychology: Child, 14: 11-12. doi:10.1080/21622965.2018.1550403

Norbury CF, Gooch D, Wray C, Baird G, Charman T, Simonoff E, Vamvakas G, Pickles A (2016). The impact of non- verbal ability on prevalence and clinical presentation of language disorder: evidence from a population study. Journal of Child Psychology and Psychiatry, 57(11): 1247-1257. doi:10.1111/jcpp.12573

Paul R, Norbury C, Gosse C (2017). Language disorder from infancy through adolescent. Fifth Edition. Elsevier.

Rudolph JM (2017). Case history risk factors for specific language impairment: A systematic review and meta-analysis. American Journal of Speech-Language Pathology. 26(3): 991-1110. doi:10.23641/asha.5150122

Sari S, Memy Y, Ghanie A (2015). Angka kejadian delayed speech disertai gangguan pendengaran pada anak yang menjalani pemeriksaan pendengaran di bagian neurootologi IKTHT-KL RSUP Dr. Moh. Hoesin. Jurnal Kedokteran dan Kesehatan, 2(1): 121-127. Retrieved from https://e.jour-nal.unsri.ac.id/index.php/jkk/article/view/2543

Shipley KG, McAfee JG (2015). Assessment in speech-language pathology. Fifth Edition. Delmar: Cengage Learning.

Stolarova M, Brielmann AA, Wolf C, Rinker T, Burke T, Baayen H (2016). Early vocabulary in relation to gender, bilingualism, type and duration of childcare. Advances in Cognitive Psychology, 12(3): 130-144. doi: 10.5709/acp-0192-6 Sudarman, Mangunsong RRD (2019). Pengaruh pola asuh dan pola bermain terhadap kemampuan komunikasi sosial pada anak autism di Surakarta (The effect of parenting and playing patterns on the ability of social communication in children with autism in Surakarta). JurnalTerpaduIlmuKesehatan, 8(2): 158-161. Retrieved from http://jurnalinterest.com/index.php/int/article/vie $\mathrm{w} / 171 / 130$. 
Susanti et al./Association between Receptive Language Skill and Social Communication Skill

Swineford LB, Thurm A, Baird G, Wetherbt AM, Swedo S (2014). Social (pragmatic) communication disorder: a research review of this new DSM-5 diagnostic category. J NeurodevDisord, 6(41): 1866-1955. doi: 10.1186/1866-1955-641

Umek LM, Peklaj UF (2017). Gender differences in children's language: a metaanalysis of slovenian studies. Center for Educational Policy Studies Journal, 7(2): 97-111. http://eric.ed.gov/?id=EJ1145869

Volkom MV, Guerguis AJ, Kramer A (2017). Sibling relationship, birth order and personality among emerging adults. Journal of Psychology and Behavioral Science, 5(2): 21-28. doi: 10.15640/jpbs.v5n2a3

Yildiz TG, Gonen M, Erdem AU, Gracia A, Raikes A, Acar IH, Burcak A, Turan F, Gul SC, Davis S (2019). Examining the associations between children's receptive language skills and developmental domains in the United States and Turkey. Journal of Child Language, 46(3): 480-500. doi:10.1017/So305000918000570 